\title{
Kant’s Emergence and Sellarsian Cognitive Science
}

\author{
Richard McDonough \\ Singapore Campus, The Arium Academy, Singapore City, Singapore \\ Email: rmm249@cornell.edu
}

Received November $5^{\text {th }}$, 2013; revised December $5^{\text {th }}$, 2013; accepted December $12^{\text {th }}, 2013$

Copyright (c) 2014 Richard McDonough. This is an open access article distributed under the Creative Commons Attribution License, which permits unrestricted use, distribution, and reproduction in any medium, provided the original work is properly cited. In accordance of the Creative Commons Attribution License all Copyrights (C) 2014 are reserved for SCIRP and the owner of the intellectual property Richard McDonough. All Copyright (C) 2014 are guarded by law and by SCIRP as a guardian.

The paper argues, against current views that see Kant as giving abstract descriptions of cognitive mechanisms (after the fashion of functionalism in cognitive science), that Kant sees mental phenomena as akin to emergent phenomena in a sense traditionally opposed to mechanism. After distinguishing several relevant notions of emergence, the paper distinguishes several of Kant's basic emergentist theses, including his emergent materialism in chemistry and a species of mental emergence modelled on that chemical emergence. However, Kant's doctrine of the epigenesis of pure Reason is argued to be Kant's most fundamental emergentist thesis. The paper argues that Kant's notion of mental emergence sheds light on some very puzzling aspects of his remarks about the unity of intuition and concept emphasized by Wilfrid Sellars. The paper sketches some of the problems in contemporary cognitive science and shows how a Sellarsian emergentism inspired by Kant addresses some of these problems and provides an interesting alternative to the kind of mechanistic positions that have tended to dominate the field. Finally, the paper locates the present emergentist reading with respect to the perspectivist reading of Kant.

Keywords: Kant; Sellars; Emergentism; Functionalism; Epigenesis

[Transcendental philosophy is] a system of the ideas of pure reason insofar as they emerge from reason synthetically and a priori.

Kant, Opus Postumum (247) ${ }^{1}$.

For Kant, the world emerges from the subject; for the philosophy of organism, the subject emerges from the world.

Whitehead, Process and Reality ${ }^{2}$.

\section{Introduction}

The view that Kant is a forerunner of the program in cognitive science (hereafter $\mathbf{C S}$ ) to describe the mechanisms that underlie cognition is accepted by many contemporary scholars (Kitcher, 1984; Zumbach, 1984; Kitcher, 1990a; Kitcher, 1990b; Meerbote, 1990; Brook, 2008; etc.). Kitcher, who has done more than anyone to promote this reading, claims that Kant makes no mention of cognitive mechanisms because he is a functionalist who only gives abstract descriptions of cognitive tasks and is uninterested in their physical realization (1990b, 115, 206, 266 note 16; 1990a, 19, 22, 28, 75; See also Brook, 1994, 12-14) ${ }^{2}$. Kitcher (1990a, 209 note 21) accepts that Kant may not see his views as CS but claims that contemporary scholars should see them as $\mathbf{C S}$.

\footnotetext{
${ }^{1}$ The abbreviations to Kant's works, in bold italics, are: Critique of Pure Reason [C1]; Critique of Practical Reason [C2]; Critique of Judgment [C3]; Opus Postumum [OP]; Metaphysical Foundations of Natural Science [MF]; Prolegomena to any Future Metaphysics [PFM]; Anthropology from a Practical Point of View [ANTH]; 'What is Enlightenment?' [WE]; References to $C 1$ are to standard A and B edition page numbers. References to Kant's other works are, unless otherwise indicated, by page number.

${ }^{2}$ Meerbote $(1990,161-188)$ agrees that Kant is a functionalist but thinks he is interested in their physical realizations.
}

Kant does not, however, merely fail to refer to these underlying mechanisms. His works are filled with vehement denouncements of materialism and mechanism ${ }^{3}$. The present paper argues that Kant has no interest in such mechanisms because he sees cognition as akin to an emergent phenomenon in a sense traditionally opposed to mechanism (Clayton, 2006; Palmquist, 2007; Reid, 2007; McDonough, 2011). Kant's immediate successors, Fichte, Schelling, Hegel, etc., did not see anything remotely like CS in Kant and several of them went on to develop emergence-like views out of Kant (Popper, 1950, 232, 646 note 25). CS was simply not part of the milieu in which German Idealism arose. The transformation of Kant's views into a more materialistic and mechanistic form was initiated later by Helmholtz, largely in reaction against the way Kant had been understood by his Idealistic successors (Fancher, 1990, 110-128). Further, after a long period in exile, emergentism has again (due, in part, to the problems with the machine model in CS) become a respectable position in science and philosophy (Bunge, 1977; Margolis, 1986; Margolis, 1987; Kim, Beckermann, \& Flores, 1992; Davidson, 1999; Hasker, 1999; McDonough, 2002; Shoemaker, 2002; Clayton \& Davies, 2006; Brighton, 2008; Corradini \& O’Connor, 2010; etc.). Furthermore, a Kantian view, with affinities both to $\mathbf{C S}$ and to emergentism, has been

\footnotetext{
${ }^{3}$ At C1(A383) Kant warns against "the danger of materialism" and at (B42, B421) against "soulless materialism." See also C2 (100-101); PFM (100, 111); MF (Preface); OP (177); WE (45-46); Brook, 1994, 14-23; McDonough, (1995); McDonough, (1997), and McDonough (1998). ${ }^{4}$ Seibt $(1990,240-241)$ ascribes a minimalist species of emergentism to Sellars but it is clear that, following in his father's footsteps (Sellars, Roy Wood 1970), he embraces a more robust emergentism. See "Kant's Chemical Analogy and Chrucky” (2008).
} 


\section{R. MCDONOUGH}

developed by Wilfrid Sellars ${ }^{4}$. The present paper argues that Sellars' blend of materialism with a quasi-Kantian emergentism may provide a partial antidote for some of what ills $\mathbf{C S}$.

The first section discusses the crisis of confidence in contemporary cognitive science. The second clarifies the relevant notions of emergence. The third discusses Kant's emergentist theses concerning chemical and mental production. The fourth argues that Kant's notion of the epigenesis of pure Reason is his core emergentist view. The fifth shows how Kant's emergentism shed light on a puzzling aspect of the Kantian text emphasized by Sellars. The sixth sketches the application of Sellars' quasi-Kantian emergentism to CS. The seventh argues that Sellars' quasi-Kantian emergentism provides an alternative to the functionalist paradigm that has been so central in CS. The eighth briefly locates the present view in relation to the "perspectivist" reading of Kant.

\section{The Crisis of Confidence in Cognitive Science}

[T] he analogy between people and machines is pretty exact.

Fodor, The Language of Thought (118)

Since it cannot be magic, there must be mechanisms.

Churchland, Neurophilosophy (461-461)

Since the development of powerful modern computing machines around the 1940's many philosophers and scientists simply have taken it for granted that it was only a matter of time before satisfactory machine models of human intelligence were produced (Adler \& Adler, 1962). Numerous philosophers and scientists refer confidently to "the mechanisms of cognition" (Pinker, 2013, xi, 1-5, etc.). Reversing Descartes' view that only a non-machine can think, Searle has claimed that only a machine can think (Searle, 1980). McGinn expresses the common view that there "just has to be" some mechanistic explanation of the way brains subserve minds (McGinn, 1989, 353). Churchland thinks that abandoning mechanism is tantamount to embracing magic (see epigraph above).

The early enthusiasm for such mechanistic theories has not, however, produced the expected results. The dominant model for decades has been the Computational Theory of Mind (CTM), the view that the mind is something like a machine that computes over mental representations. But though Fodor has been one of the chief proponents of CTM, he claims never to have succumbed to the general enthusiasm. Even as he wrote book after book praising CTM, Fodor $(2001,1)$ states that had always taken it for granted that no one really thought that itwould provide more than a fragment of the total account-an assumption of which he has since been disabused. After recounting the "glaring" problems with CTM, he (2001, 39) concludes that "much of the field is in deep denial"

One of the key problems for CTM is that mental representations must have (broadly speaking) "semantic" properties, but no one has shown how they can possess such properties (Fodor, 1987, xi). Against this background, rehearsing the slogans of an antiquated "mechanistic imperialism" (Weiskopf, 2011) sounds more like desperation than argument and gets one no further towards a workable theory. If the machine model of CTM appears to be a degenerating research program ${ }^{6}$, what alternatives are left?

It turns out that Wilfred Sellars, following in his father's

\footnotetext{
${ }^{5}$ See also Dartnall, 1996; and Fodor, 1998.

${ }^{6}$ For a discussion of degenerating research programs see Hansson (2008), § 4.4.
}

footsteps (Sellars, Roy, 1970), favored an emergentist approach. Thus, a sophisticated emergentist position akin, in many other respects, to CS is already present in the Wilfrid Sellars' philosophy of mind. Given the "glaring" problems with CTM, the paper argues that it is time to consider this emergentist alternative.

\section{The Notion of Emergence}

The higher quality emerges from the lower level of existence and has its roots therein, ... [but] it ... constitutes its possessor a new order of existent with its special laws of behavior. The existence of emergent qualities ... is [to be] accepted with the "natural piety" of the investigator.

Alexander, Space, Time, and Deity (46-47)

To a lot of scientists [in the $20^{\text {th }}$ century], emergence was regarded as, at best, an irrelevant anachronism, at worst, a vestige of vitalism. But during the last [few] decades, the mood has shifted ...due to the rise of ... chaos theory, ...non-linear systems, and self-organizing systems.

Davies, The Re-Emergence of Emergence (Preface)

Emergence is, most generally, understood as the emergence of novelty, e.g.., mind is in some obvious non-trivial sense novel relative to the brain matter that produces it (Nagel, 1979, 374-380). Emergent materialists hold that higher levels, e.g., life and mind, supervene on lower material levels, but deny that the higher levels are reducible to the lower levels (Morgan, 1923; Goudge, 1967; Popper, 1961; Davidson, 1999; O’Connor, 2012), leaving an explanatory gap between emergent phenomenon and any underlying mechanism (Achim, 1992, 41 note 17; Kim, 1992, 127 note 15; Guick, 1992, 161, 176). Emergentism can be formulated as a metaphysical theory, about the relation between entities, or linguistically, as a relation between theories (Nagel, 1979: 368-369). Since Kant's formulations are metaphysical, these are followed here. Many philosophers have held that the assertion of emergence is an admission of ignorance because what seems emergent relative to current knowledge may not be so tomorrow (Hempel, 1965: 260, 261). The appeal to emergence is often seen as an admission of failure, producing much of the traditional hostility to it (See Russell, 1992; Hempel, 1965; Kim, 1993).

Emergentism can be divided into epistemological and metaphysical varieties. Epistemological emergence is the view that human beings cannot know how $\alpha$ (e.g., mind) reduces to $\beta$ (e.g., matter), even though, if one were omniscient, one might see that $\alpha$ reduces to $\beta$ after all. To say that $\alpha$ is epistemologically emergent from $\beta$ is not to say that $\alpha$ is irreducible to $\beta$, but only that it seems that way to human beings. Nevertheless, epistemological emergence might be quite interesting: One might claim that knowledge of the reduction of $\alpha$ to $\beta$ is, in principle, closed to human beings because of the limitations of human cognition (Cf. McGinn, 1989). It seems clear that Kant is at minimum an epistemological emergentist since he holds that the "appearances" are produced by things-in-themselves but that this relation is unknowable by humans (Schrader, 1967b: 172). It must, for Kant, seem to human beings that the appearances are emergent from things-in-themselves with his proviso that an intuitive understanding, like God's understanding $(C 1$, B72, B145; See Strawson, 1968: 41), might be able to know this relation. The present paper, however, focuses on metaphysical emergence.

Metaphysical emergence can be divided into the emergence exhibited by "organic wholes" (synchronic emergence) and 
emergent-evolution (diachronic emergence) (Rueger, 2000). In synchronic emergence, the emergent exists simultaneously with its basis (e.g., cognition exists simultaneously with its neural basis). Emergent evolution, defended by Alexander (1920), Morgan (1932), Roy Wood Sellars (1970), Popper (1972), Popper (2002) and others, is, roughly, the view that the laws of nature evolve over time (Nagel, 1979: 374-378). Analogous views are held by Bergson (1944) and Hegel (See Popper, 1956, 232, 646 n 25 and Clayton, 2006). Kant describes the creation of the cosmos in C3 (para. 80) in terms suggestive of emergent evolution, but it is a principle of "reflective judgment" and is not pursued here ${ }^{7}$.

Synchronic emergence is, roughly, the view that certain "organic wholes,” usually but not exclusively living organisms, display a hierarchy of levels, physical, chemical, biological, psychological, etc., where items at a higher level supervene on items at the lower levels but are not a mere additive sum of the items at those lower levels (Broad, 1925; Margolis, 1987). The most common species of synchronic emergence in the Anglo-American tradition is emergent materialism, which arose in response to the perceived inadequacies of reductive materialism $^{8}$. Emergent materialists reject the reduction of life and mind to matter, but, since they also reject vitalism, hold that the living material organism is, as it is said, "greater than the sum of" its material "parts."

G.E. Moore generally rejected the view, which he associated with Hegel, that certain wholes are "greater than the sum of their parts," but made an exception in aesthetics. His "principle of organic unity" is that "the value of a whole must not be assumed to be the sum of the values of its parts (Moore, 1994: 79-84). His example is that neither consciousness nor beautiful objects are particularly valuable by themselves, but there is an increase in value when they are combined (when consciousness experiences beautiful objects).

Most philosophers do not object to Moore's value-emergence. Pepper (1926) argued that any metaphysically emergent items must be epiphenomenal. Thus, the most controversial species of emergence is the species that asserts the emergence of new causal forces. On Pepper's view, if, for example, consciousness is an emergent property of neural organization, no new causal powers over and above those already present in the neural structures are added by the emergence. Although epiphenomenal emergence is a species of metaphysical emergence, it, like Moore's value-emergence, does not threaten conservation laws in physics and so is not metaphysically threatening (Lowe, 2000).

Wilfrid Sellars (1956) argues against Pepper that there may be emergent downward causation (or emergence ${ }_{\mathrm{dc}}$ ), i.e., items that "break the laws" at the lower level (e.g., sodium may have different causal powers in living systems from those it has in the laboratory). Emergence ${ }_{\mathrm{dc}}$ is the species of synchronic emersgence of central importance in the present paper. The following section argues that Kant endorses emergence $\mathrm{dc}_{\mathrm{dc}}$ in chemistry and holds that mental production is analogous to chemical production.

\section{Kant's Chemical Analogy for Mental Emergence}

Despite their dissimilarity, understanding and sensibility

\footnotetext{
${ }^{7}$ Kant's $\boldsymbol{O P}$ (66-67) defends a similar doctrine not qualified as mere 'reflective judgment' (McDonough, 2011, §. 3).

${ }^{8}$ Marx's "dialectical materialism" is also a response to the perceived inadequacies of “mechanical materialism.” See Engels (1994, Part II).
}

form a close union for bringing about cognitions, ...

The first two kinds of composition of perceptions could be called mathematical (of enlargement), but the third would be called dynamical (of production) whereby an entirely new entity arises (something like a chemical compound). The play of powers in inanimate nature, as well as the animate, in the soul as well as the body, is based in the separating and uniting of the dissimilar. ...[I]t seems impossible that organic creatures can originate from matter ... in any other way than by the two sexes established for this purpose.

Kant, Anthropology from a Practical Point of View (68 and footnote to 68)

This experiment in pure reason bears a great similarity to what in chemistry is [called] the experiment of reduction, or more usually, the synthetic process.

Kant, Critique of Pure Reason (note to Bxxi)

Kant's Anthropology describes the production of a chemical compound (e.g., salt from sodium and chlorine) as the "arising" of an "entirely new entity.", But if an entirely new entity C arises in the chemical reaction of $\mathrm{A}$ and $\mathrm{B}$, then $\mathrm{C}$ is metaphysically emergent.

The view that salt is an entirely new emergent entity means that it is not composed of sodium and chlorine but rather replaces those elements. Wallace $(1894,65)$, in his discussion of Hegel, remarks that "the philosopher" will "tell the chemist" that his picture of water as "an atom of oxygen locked away with an atom of hydrogen" is "mythological" and not the "wellascertained chemical truth" that the chemist thinks it is ${ }^{10}$. In fact, Hegel's view derives from Kant. Call the view that the emergent entity is a unitary whole the principle of the Unitary Wholeness of Emergent Substances (UWES) and call the related view that all of the parts of emergent item $\mathrm{X}$ are themselves $\mathrm{X}$ (all the parts of salt are salt), the principle of the $\mathrm{Ho}$ moeoereity of the Emergent Substance (HES) ${ }^{11}$.

Since Kant individuates substances by reference to their "action,” i.e., causal powers (C1, A204/B249), the emergence of new chemical substancesis, ipso facto, the emergence of new causal forces. Call this the principle of Emergent Downward Causation in emergent substances (EDC). The causal properties of the sodium, i.e., to 'burn' in water, and of chlorine gas, i.e., to irritate the human respiratory system, are replaced by the new property of lowering the boiling point of water.

In some classical versions of emergentism, the original elements are not present in the emergent substance, but some of their properties remain. Discussing the concept of emergent hierarchies in the Aristotelian tradition, Wilfrid Sellars $(1949,563)$ writes.

For the Scholastic ... it is a confusion to think of higher level substances including lower level substances. ... [T]

\footnotetext{
${ }^{9}$ Kant's language concerning chemical production is similar to Mill's formulation of 'heteropathic laws' in chemistry and psychology-themselves precursors of emergentism (McLaughlin, 1992). While Mill (1999, 39) speaks of chemical elements "melting into each other," Kant speaks of them as “dissolving into" or "interpenetrating” each other. See also Wallace (1894 $161,271,274,307)$ and O'Connor (2012, § 3.2.2). For an historical note on a possible connection between Kant and Mill see McDonough (2011, 255). ${ }^{10}$ Wittgenstein $(1980,71)$ suggests a remarkably similar view.

${ }^{11}$ Some scholars see Anaxagoras' principle of homoeomereity to be inconsistent with his principle that "in everything there is a bit of everything." See Allen (1966, 5-6). A more charitable reading is that Anaxagoras is struggling to conceptualize the difficult view that certain elements combine to form a unitary emergent substance which, however, does not retain these elements as distinct constituents. For an overview of emergentism in the late pre-Socratics see Mourelatos (1986).
} 


\section{R. MCDONOUGH}

tial forms of higher level substances include the [lower level] substances only "virtually" by including their properties modified to fit their higher estate.

Sellars (1949, 569 n 29) illustrates with a graphic example,

[I]f you kill an elephant, earth, air, fire, and water, which were present in the living elephant only as physical properties, come into existence as substances.

The "earth," which went into the making of the elephant, is not present in it as a substance, but its properties are (e.g., the elephant is "earth-like"). Call this the principle of Elementary Property Expression in emergent substances (EPE).

One important feature of Kant's account of chemical emergence in $A N T H$, which he extends to biological emergence, is that it requires a combination of opposites, "the separating and uniting of the dissimilar.” In chemistry these are positive and negative valances, in biology, the two sexes. Kant's dynamical view of mental synthesis, further developed by Hegel (Wallace, 1894, 128, 153-154), Schelling (Watson, 1892, 91-97), and others, is that it is only from a union of opposites that a new "synthesis" emerges ${ }^{12}$.

Since $A N T H$ and $C 1$ compare chemical and mental synthesis, analogous conclusions hold for mental synthesis. The "analytic" method of his Prolegomena and the "synthetic" method of $C 1$ are compared, respectively, to the "analytical" and "synthetic" methods in chemistry ( $C 1$ note to Bxxi \& note to B395). Since ANTH holds that chemical synthesis involves the emergence of new substances and new causal forces, one should find cases in C1 where mental production involves the emergence of new entities.

One of the "nice" ( $C 1, \mathrm{~B} 109)$ points Kant makes about his table of categories is that the third category in each set is produced by combining the first two, e.g., "community is... the causality of substances reciprocally determining each other" (B111). The third category is not a mere sum of the first two since it "requires a special act of the understanding not identical with" the one involved in production of the first two (B111). Like the salt produced from sodium and chlorine, the third category is, so to speak, "greater than the sum of its parts." Like many current philosophers, Kant has a "mental chemistry" model of mental synthesis ${ }^{13}$, but since Kant has an emergentist model of chemistry, his account of mental synthesis takes a very different form to these current models. This is reflected in his account of the epigenesis of pure Reason.

\section{The Epigenesis of pure Reason}

There are only two ways we can account for the necessary agreement of experience with the concepts of its objects: either experience makes these concepts possible or these concepts make experience possible. The former supposition does not hold of the categories (nor of pure sensible intuition)...

There remains ... only the second - a system ... of the epigenesis of pure reason ...

Kant, Critique of Pure Reason (B167)

Kant endorses a view (epigenesis) on which the emergence of an apparently new [organism] is not just the expansion or unfolding of one existing in miniature (as on the preformationist view) but a natural process whereby a new living thing comes into being.

\footnotetext{
${ }^{12}$ This idea is also found in dialectical materialism. See note 8 above.

${ }^{13}$ See Savin $(1973,212-238)$, Fodor $(1979,96)$ and McGinn (2004) on the notion of mental chemistry!
}

Grisborg, "Kant”s Aesthetics and Teleology” (§ 3)

Kant identifies his signature idea in $C 1$, that concepts make experience possible, his 'Copernican Revolution in Philosophy' (Bxvi), with the notion of epigenesis usually applied to the evolution of life. $C 1$ gives an account of the epigenesis (generation) of knowledge while $C 3$ provides an account of the evolution of living forms ${ }^{14}$.

In C3 (Sec's. 81, 88), the theory of preformation, which treats organisms as educts, is contrasted with Kant's theory of epigenesis, which treats them as products. Pluhar explains that to "produce" something involves giving it form, while to educe something is to "bring out" a form that is already present (Pluher, 1987, $250 \mathrm{n}$ 31). The epigenesis of living forms involves the generation of novelty that typifies emergence. If a plant arises from a seed but it is not "preformed" in the seed, then it is emergent from the seed. The view that all possible forms of living creatures are present (preformed) at creation is the theory of preformation $(C 3, \S 81)$. The view that new living forms emerge over time (are "produced by nature," C3, Sec, 81), is the theory of epigenesis.

Since Kant holds that mental synthesis is analogous to chemical synthesis, which latter involves the emergence new substances and causal powers, and since $C 1$ compares the genesis of the system of pure reason with the genesis of living forms, one should not be surprised to find similar views in Kant's account of mental epigensis.

Systems seem to be formed [like] lowly organisms, through a generation aequivoca from the confluence of assembled concepts, at first imperfect, only gradually attaining to completeness, although they one and all have their schema, as the original germ, in the sheer self-development of reason. Hence, not only is each system articulated in accordance with an idea, but they are organically united in a system of human knowledge, as members of one whole, ... (C1, A835/B863).

Just as, in C3 (note to § 80), Kant holds that the generation aequivoca of living-forms is absurd, Kant's point here is that though systems seem to arise in a process of generatio aequivoca, they are actually articulated in accord with the idea of reason of a unitary organic system of knowledge. Kant's describes the origin of this idea of unity,

[W] shall begin at the point from which the common root of our faculty of knowledge divides and throws out two stems, one of which is reason. By reason I here understand the whole higher faculty of knowledge [thereby] contrasting the rational with the empirical (C1, A835/B863).

The arising of the system of knowledge is compared to the arising of a plant from two stems, "the rational" and "the empirical” (understanding and sensibility), which, in turn, arise from a "common root." The "idea" of the unitary organism of knowledge is implicit in that single "root." Sensibility and understanding are the two "stems" of this organism. Just as the genesis of an emergent chemical substance requires a synthesis of opposites, the genesis of knowledge requires the synthesis these opposing faculties. Following the chemical analogy, knowledge as an emergent product of that union of opposites.

What, however, guarantees that these opposite faculties can combine to produce knowledge? Kant's answer is that since they spring from a single "root," they must be united under a single idea (like the "parts" of a unitary organism). Since Kant sees knowledge as an emergent product of the union of sensi-

\footnotetext{
${ }^{14}$ Kant does not use the word 'evolution' in its precise contemporary sense (Pluher, 1987, 309 \& n 11).
} 
bility and understanding, his picture of emergence, implicit in his chemical-psychological analogy, applies to his account of the genesis of knowledge.

\section{The Emergence of Cognition}

“Our knowledge," [Kant] tells us, "springs from two fundamental sources of mind; the first is the capacity for receiving representations (receptivity), the second is the power of knowing an object through these representations (spontaneity). ... Alas! This neatness soon falls victim to the exigencies of the argument. "Intuition" turns out to be Janus-faced, and the understanding has its own mode of receptivity...

One is tempted to say that Kant is fighting his way towards a clarity of structure which he never achieves and which is in his thinking only as the oak is in the acorn.

Sellars, Science and Metaphysics (2)

Since the epigenesis of pure reason is closely connected with the genesis (and therefore the nature) of human cognition, the emergentist interpretation of epigenesis should shed new light on the nature of those cognitions. The present section attempts to illustrate this by showing how a puzzling aspect of Kant's remarks about intuitions, emphasized by Sellars, is clarified by the emergence-model.

Although $C 1$ begins with the view that empirical knowledge arises from the union of sensibility and understanding, all actual cases of empirical knowledge, e.g., Bob”s knowledge of thiscube, constitute a seamless whole. Though one can "analyze" such knowledge into an intuition-portion and a concept-portion, one cannot, despite the wishful thinking of sense-datum theorists (and, perhaps, some classical empiricists), cleanly separate the two ${ }^{15}$. Since knowledge is generated from two opposite faculties, sensibility and understanding, it is necessary to explain how instances of such knowledge can form a seamless whole. Second, one must explain why, despite their seamless unity, it is still useful to analyze them into an intuition-component and a concept-component.

Despite Kant's initial sharp distinction between sensibility and understanding, his view that knowledge forms a single unified system, analogous to a living organism (C1, A835/ $\mathrm{B} 863$ ), is central to his argument in $C 1$. His argument that the world of experience displays a spatial, temporal, and categorical structure is based on his view that since all contents of consciousness must belong to one single self-consciousness (A106$108,110 / \mathrm{B} 131-2$, etc.), they must conform to the spatial, temporal, and categorical structure that it requires. However, Kant's initial oversimplified picture in the Aesthetic posits just that sort of unconnected contents of consciousness-the presynthesized data of sensibility (B129). Do the raw data of sensibility belong to the single embracing self-consciousness or not? If they do, they must conform to the same spatial-temporal-categorical structure required of all contents of consciousness-but then they are not raw unconnected data of sensibility. If, however, they do not belong to that single self-consciousness, they are not available to consciousness for synthesis. Kant is in a prima facia bind. How is one to understand the shift from his initial oversimplified view of sensible intuitions in the Aesthetic to the more sophisticated view emphasized by Sellars?

In fact, the shift between Kant's initial oversimplified view

\footnotetext{
${ }^{15}$ Pears (1987, 3-20) ascribes an analogous insight to Wittgenstein. An analogous point is also at the core of Quine (1951).
}

of sensible intuitions and the later more refined view corresponds to the difference between the analytic and synthetic methods, understood on the emergentist model, and applied to Kant's account of mental production. When Kant compares his experiment in pure reason with "the experiment of reduction" or "the synthetic process" in chemistry ( $C 1$, Bxxi note a), he means the process of reducing (analyzing) a chemical "compound," e.g., salt, into its two "elements," sodium and chlorine $^{16}$. Thus, employing the "analytical” method of the Prolegomena, Kant "analyzes” ("reduces”) knowledge into its "elements," sensibility and understanding. By contrast, $C 1$ begins with the fruits of that "analysis" and employs the "synthetic method" to recombine them into the unitary whole of knowledge. Thus, Part I of the Prolegomena begins by adverting to a whole given body of knowledge: "Here is a great and established branch of knowledge [mathematics], ...”PFM (28), while $C 1$ (A15/B29) begins precisely at the other end (with the elements) and attempts to "synthesize" them into the whole: "[T]here are only two stems of human knowledge, namely, sensibility and understanding, ...” The Prolegomena begins, as it were, with the "salt," and analyzes it to its elements, while $C 1$ begins with the elements, and synthesizes them, as it were, into the "salt." Whereas the Prolegomena begins with the established wholes of knowledge from ordinary life, $C 1$ begins with the "elements" of knowledge, sensibility and understanding, which are never encountered in ordinary life (leading to the inevitable "strangeness" in the landscape in $C 1)^{17}$.

In order to see how Kant's emergentist chemical model sheds light on his views about the seamless whole of sensible intuitions, recall from $\S$ II that, on Kant's view, 1.) The combination of sodium and chlorine is an emergent substance, salt, with emergent downward causal powers (EDC), 2.) The emergent substance, salt, is a unitary whole (UWES), 3.) That whole is a homogeneous substance that replaces, and does not contain, the "elements" from which it is synthesized (HES), but 4.) Though the emergent substance replaces the original elements, some properties of the original elements may remain in the emergent substance (EPE). Against this background, consider Kant's account of the union of sensibility and understanding to generate knowledge.

First, just as the salt has emergent powers that are not the mere sum of the powers in sodium and chlorine, so too, human knowledge has emergent causal powers that are not the mere sum of those of sensibility and understanding (EDC). If Bob's knowledge of this-cube is an emergent product of intuition and concept, then, when Bob uses the word "cube" to describe a cube, he is acting in ways not possible for beings possessed solely of sensibility without understanding (lobsters) or solely of understanding without sensibility (angels), and he acts in this way because of the special powers conferred on him by his (emergent) concept-intuition unitary whole ("this-cube").

Second, just as the original elements of the salt, sodium and chlorine, are not present in the salt as separable constituents, so, as Sellars stresses, intuition and concept are not present in the emergent knowledge as separable constituents. The "knowledge" produced by the combination of sensibility and understanding,

\footnotetext{
${ }^{16}$ It is worth stressing that Kant's notion of chemical reduction is virtually opposite in meaning to the contemporary notion of reductionism. In fact, Kant's notion of the reduction of a chemical compound into its elements is consistent with an emergentist view of the chemical synthesis of the compound out of its elements.

${ }^{17}$ Commentators as diverse as Heidegger $(1962,62,98,119)$ and Strawson $(1966,148)$ comment on the 'strangeness' of these Kantian doctrines.
} 
is, like the salt, a unitary emergent whole (UWES). Further, since, on Kant's emergentist view of chemistry, one cannot divide the salt into the sodium-part and the chlorine-part, but, rather, all the parts of the salt are salt (HES), and since knowledge production is analogous to chemical production, one cannot divide the knowledge into one part that is intuition and another that is concept. Rather, all of the "parts" of knowledge are knowledge. One can divide Bob's knowledge of this icecube into knowledge that this is ice and knowledge that this is a cube, both of which are full-blooded instances of knowledge involving both intuition and concept in a unitary whole. But one cannot divide it into one part that is only intuition, the "this" part $^{18}$, and another that is the concept part, "cold."19

If, however, the knowledge that emerges from the union of sensibility and understanding does not contain an intuitioncomponent and a concept-component as separable constituents, then why are the concepts of intuition and concept useful for understanding knowledge? The answer is that just as some of the properties of the sodium and chlorine may be reflected in the salt even though those elements are not present as constituents in the salt, some of the properties of intuition and of concept can be reflected in the emergent unitary knowledge even though they are not present in it as constituents (EPE). The real life intuition of this-cube possesses some of the properties of sensibility and some of those of understanding even though sensibility and understanding are not present in the intuition as separable constituents - which explains why the analysis of knowledge into sensibility and understanding is still useful. The emergence of knowledge from its "elements” precisely parallels the emergence of salt from its atomic "elements"-which explains Sellars' point that for Kant intuition and concept cannot be separated in sensible intuitions (any more than the sodium and chlorine can be separated in the unitary substance, salt, that emerges from their union).

\section{Application to Cognitive Science}

[I]f I build my discussion of contemporary issues on a foundation of Kant exegesis and commentary it is because... there are enough close parallels between the problems confronting him and the steps he took to solve them, on the one hand, and the current situation and its demands, on the other, for it to be helpful as a means of communication, though, not, of course, as a means only.

Sellars, Science and Metaphysics (1)

No philosopher understands his predecessors until he has rethought their thought in his own contemporary terms, ...

Strawson, Individuals (xv)

Any contemporary adaptation of Kant's views must make major changes to Kant's framework. However, a suitably modified quasi-Kantian emergentim provides a useful model for contemporary (predominately materialist) CS. Since the present paper relies heavily on Sellars' reading of Kant, and since Sellars reformulates the Kantian system in modern emergentist scientific terms (Rosenberg, 2009, § 2; See also Seibt, 1990, 240-241), the present section shows how Kant's emergentism provides a useful avenue for addressing the contemporary crisis

\footnotetext{
${ }^{18}$ Hegel (1979, para's 90-110) exposes the incoherence of intuition with no conceptual aspect. See also Wallace (1894, 306-7) and note 19 below.

${ }^{19}$ Kant's official view is that the "pure" concepts of the understanding have no trace of intuition, but see Schrader (1967a). Philip Kitcher (1982, 217250) also argues that the Kantian text undermine some of his official dualisms. See note 18 above.
}

of confidence in $\mathbf{C S}$.

Since Kant opposes a materialist account of mind ( $C 1$, B429 $)^{20}$, Sellars must recast Kant's view in a form that departs from Kant's official position. It also requires that Kant's allegedbifurcation of the self into transcendental and empirical selves must be rejected in favor of a unitary materialist notion of the self (Cf. Buchdahl, 1992, 132) ${ }^{21}$.

Although Sellars does not claim that his emergentism derives specifically from his reading of Kant, the two emergentist applications discussed earlier find suggestive parallels in Sellars. As argued earlier, Sellars holds that Kant's intuitions and concepts are not the cleanly distinct items... he initially makes them out to be but are always found, in real cases, united in a seamless whole-and it is Kant's analogy between chemical and mental synthesis that provides the explanation why Sellars' observation is correct. Just as a unitary emergent chemical entity arises from distinct chemical elements, and possesses some of the properties of those original elements, but does not contain those elements as constituents, so a unitary emergent case of knowledge arises from its original "elements” (intuition and concept), and possesses some of the properties of those elements, but does not retain them as distinct constituents ${ }^{22}$.

Sellars does not explicitly lay out an emergentist scenario like that attributed to Kant earlier, but it can be inferred from his remarks that, in some cases at least, he accepts something like it. In his account of sensa, Sellars (1991b, 104-5) writes,

[W] hen an ideally completed neurophysiology interprets [its] physical concepts ... in terms of the spatio-temporally punctiform particulars of an ideally completed micro-physics, sensa might [appear] as one qualitative dimension among others ... which exist only in neurophysiological contexts.

Sellars (1991b, 105 n 1) refers one to his (1956) defense of emergence for his view of the relation of sense to neurophysiological states. This means that in an ideally completed neurophysiology, sensa, which correspond to the sensory qualities, like pink, of the "manifest" framework, might turn out to be emergent states of human neurophysiology. Since sensa represent (although not perfectly) the microphysical structure of objects ${ }^{23}$, Sellars is suggesting that sense are emergent states of human neurophysiology in its interaction with items in the physical world. Furthermore, although Sellars' emergentism is most explicit in his account of sensa, he also holds that 'in light of recent developments in neurophysiology, there is no reason to suppose that there can't be neurophysiological states that stand to conceptual thinking as sensory states of the brain stand to

\footnotetext{
${ }^{20}$ Kitcher (1990b, $268 \mathrm{n}$ 42) thinks it is not clear that Kant is committed to oppose materialism.

${ }^{21}$ Note that the present author does not believe that Kant is actually committed to bifurcate the self into empirical and transcendental selves. Properly understood, he requires only a bifurcation of perspectives (See Schrader, 1967b, 172-273 and the remarks on perspectivism later in the present paper). ${ }^{22}$ One might think the present account is based on a simple misunderstanding. Specifically, even if Kant argues that cognition is an emergent product of the union of intuition and concept, he makes no mention of the emergence of cognition from matter. This is true, but not surprising since Kant rejects materialism. However, Sellars, with his updated materialist reconstruction of Kant, is a species of materialist, and that is what is at issue here. Thus, the assumption made in the present paper is that if $\mathrm{x}$ is the material basis of intuition I, and $\mathrm{y}$ is the material basis of concept $\mathrm{C}$, and cognition Cog is emergent from the union of $\mathrm{x}$ and $\mathrm{y}$, then Cog is emergent from the union of $\mathrm{x}$ and $\mathrm{y}$.

${ }^{23}$ Roughly, the sensa that correspond to what people call sensations of pink informs the possessor of that sensa, other things being equal, of the existence of that microphysical structure in the object that, in the appropriate circumstances, tends, to produce a sensation of pink in normal human beings.
} 
conscious sensations' (Sellars, 1991a, 31). Thus, just as, in an ideally completed neuroscience, sensa may turn out to be emergent states of the neurophysiological system, it may turn out that thinking-episodes are also emergent from certain states of human neurophysiology.

One need not, however, appeal to Sellars' specific views in order to envisage an emergentist model of Kant's account of mental states. Although the present paper critiques Kitcher's reading of Kant, that sort of account is not irrevocably removed from the Sellarsian account sketched above. Though Kitcher freely speaks of cognitive mechanisms, she provides no precise account of her notion of mechanism, presumably taking this to comprise the sorts of things cognitive scientists typically count as neurophysiological mechanisms. However, when Kitcher first articulated her views emergentism had not yet reappeared on the philosophical scene and her view could be reconfigured to accommodate it. This reconfiguration might take several different forms.

First, one might simply broaden her notion of mechanism to include emergent neurophysiological items. Alternatively, since mechanism and emergentism have traditionally been seen as contraries, one might eschew the reference to cognitive "mechanisms" altogether and refer instead to material, physical, or natural processes that involve emergence. Thus, instead of saying that Kant is giving abstract descriptions of the "mechanisms" that underlie cognition, one might say that he is giving abstract descriptions of the natural processes (which may involve emergent causation) that underlie cognition. Following Sellars, one might hold that these emergent items are emergent states of human neurophysiology. However, in a more "holistic" permutation of this idea, one might argue that cognitive states are emergent at the level of the whole brain ${ }^{24}$. One might go even further and hold that they are emergent at the level of the whole organism $^{25}$. Finally, one might hold that certain mental states emerge on the human organism's interaction with the physical environment (Rockwell, 2007, 86), or, perhaps, even in their interaction with both their physical and social environments ${ }^{26}$. What all of these permutations have in common is that they are all are prepared to accept the stubborn irreducibility of mental phenomena to physical states with the appropriate "natural piety" and so they do not do the sort of violence to the "manifest image of man in the world" that inevitably seems to attend mechanistic models of mental phenomena ${ }^{27}$.

\section{The Limits of Functionalism}

I don't, by any means, have solutions for all of these problems [with semantics] that arise in belief-desire psychology. But I do have suggestions for some of them, and I believe there are other and better suggestions just waiting to be made.

Fodor, Psychosemantics (xii)

The only way of mitigating mechanism is by the discovery that it is not mechanism.

\footnotetext{
${ }^{24}$ Churchland (1986, 323-5, 460-1, etc.) associates the notion of network properties, i.e., "encoded" over the whole neural-network, with emergentism See also Eiser (1991).

${ }^{25}$ This would be a version of the view that certain features of persons emerge only at the personal level (Cf. Dennett, 1981, note to 154).

${ }^{26}$ McDonough (2002, 283-321) and McDonough (2006, 106, 110-111) argue that Heidegger and Wittgenstein hold some such position.

${ }^{27}$ Sellars' emergentist account of sense is intended as an example of the way emergentism is better suited to 'save the phenomena' than reductionism or mechanism. See Bogen and Woodward (1988) on the notion of saving the phenomena.
}

Whitehead, Science and the Modern World (76)

Since the machine model of CTM, the idea that intelligence consists in computation over mental representations, has not issued in the expected explanations of language and thought, it is past time to call it into question. Historically, the machine model in CTM is closely tied with functionalism (Levin, 2013). Indeed, one of the chief motivations for functionalism was the application, to problems in the philosophy of mind, of Turing's idea that theoretical "machines" or computers are capable of carrying out any algorithm (Hodges, 2013, § 7) (28 $^{28}$ If mentalstates are states of an organism that confer the ability to carry out algorithms, and if such states are defined by their causalfunctional role in the organism, then there is no reason why such states cannot be realized in a machine. Indeed, the first species of functionalism, proposed by Putnam (1964), was called 'machine-state functionalism' because it holds that since the ability to possess such functionally defined states is indifferent to the material composition of the "thinker," such states may equally be "realized" in a "wet" carbon-based life-form or metal machines.

Unfortunately, despite the great accomplishments of such computing machines in tailor-made skills like chess-playing, machines are still not even close to being able to simulate normal human tasks, e.g., picking a good wife or minding the baby (Dreyfus, 1993, 78; Goldberg, 1983, 193). Searle (1984, 35; 1983, 272) infers from this that ordinary metal machines may not be able to think like a human beings because only "meat machines" (like the brain) can, as he puts it, "produce intentionality.” CS has, Searle $(1984,40)$ holds, left out the essential biological features of the mechanism. But why, then, does heretain the idea that the brain is a machine at all?

On the present view, inspired by Sellars' emergentism, Searle may be right that the specific biology of the organism is important to the ability to think, but this is because the 'semantic' properties of representations are not machine states of the organism but, rather, are emergent properties of human neurophysiology-i.e., of a specific organization of carbon-compounds. On this view, the central view of functionalism that a given "program" could be realized in virtually any material may turn out to be incorrect. In this case, CTM's mistake is not that one requires a "meat machines" instead of metal machines. It is that the brain (and embedding organism) may not be much like a machine after all. That is, it may turn out that the machine-metaphor was uncritically adopted because it fit a certain narrative made popular by the rapid and impressive advances in computer technology (McDonough, 1999a). Physics abandoned the mechanistic model in the early $20^{\text {th }}$ century (D'Abro, 1939) and it is only a matter of time before the philosophy of mind begins to consider the possibility that the "semantical" properties of representational state may not "realizable" in just any material, but that they are emergent, in a sense sketched by Sellars, from specific types of organization of "wet" carbonbased human neurophysiology. There may, of course, turn out to be some role for some species of functionalism at some point in the overall account of mind, but Kitcher et al. are incorrect if their mechanistic and functionalist language is intended to exclude the kind of Sellarsianemergentism sketched earlier.

\footnotetext{
${ }^{28}$ Indeed, functionalism was not so much motivated by investigations into the way organisms are actually observed to "work," but by knowledge of how machines work and the hypothesis that this could be generalized to living organisms.
} 


\section{Kant's Perspectives}

We could ... paraphrase a famous maxim of Kant's and say: Systems without arguments are empty, arguments without systems are blind.

Palmquist, Kant's System of Perspectives (Part I, I.1)

[I]t is not a hand in any and every state... but only when it can fulfill its work, and therefore only when it is alive; if it is not alive it is not a part.

Aristotle, Metaphysics (1036b30-31)

It might be argued that the present interpretation replaces a narrow mechanistic and functionalist reading of Kant with a narrow emergentist reading. This is not the intention and explaining why may help to clarify the structure of the preceding argument. That is, the present paper has a specific limited aim, namely, to argue that Kant's views may, as many have claimed, provide a useful model for cognitive science, but that it may do so in the shape of the emergentist model sketched by Sellars rather than the more common machine model. But that does not mean that the emergentist model captures the entirety of Kant's own views.

On the "perspectivist" reading of Kant championed by Palmquist (1993) and Allison (2004), roughly, the view that Kant's works do not present a single rigid structure for dealing with philosophical problems (of the sort that the beginning student often derives from a first or a second reading of C1), Kant develops a system of perspectives, transcendental, logical empirical, and practical, for dealing with the philosophical issues with which he concerns himself. One virtue of the perspectivist approach is that it holds out the hope that Kant's text may turn out to be far more internally consistent than it is often taken to be, i.e., the seeming contradictions in the text may be eliminated by taking account of the various roles these seemingly contrary views play in the different parts in the overall system. But this means that it may be too simple to ask whether Kant is simply an emergentist, a functionalist, etc. Indeed, the present author believes that there is a substantial amount of truth to the perspectivist reading of $\mathrm{Kant}^{29}$.

The basic perspectivist insight began for the present author with the recognition that the causal principle (the Second Analogy) appears in $C 1$ to be an objective principle, but appears in C3 to be a subjective, regulative, or reflective principle (Breitenbach, 2011). Another example is the apparent shift in the way the "causality of freedom" is treated in $C 1$, where is said to remain "a problem" (A532-58/B560-586), and in C2 (Preface), where it is seen as "established." Since such shifts seem to be the rule rather than the exception in Kant's system, it is easy to label Kant inconsistent, but the perspectivist reading holds that this reflects a failure to appreciate Kant's notion of system.

On the perspectivist reading, as this author understands it, it is fruitless in such cases to haggle over whether Kant definitively comes down on one side or the other of the dichotomy at issue. What is important is, rather, to determine what specific roles the views in question play at specific parts of the overall system $^{30}$. As Palmquist (1993, Part I. I.1) puts it, the literature

\footnotetext{
${ }^{29}$ The reason the present author does not embrace the perspectivist reading tout court is, roughly, due to some uncertainty whether the various perspectives in Kant's system can be combined into a completely consistent system without some modifications.

${ }^{30}$ As the present author understands this, the place for Hegel's famed opposition to dualisms, including, ironically, his opposition to the various Kantian dualisms (Sedgwick, 2012, 6-8, 107, 159, etc.), is already prepared in Kant's system of perspectives, but this must be a matter for another occasion.
}

on Kant sometimes resembles the reports from the blind men who encountered the elephant: Each one can describe the part that he touched, but one might "fail to recognize the beast from their descriptions”. It simply will not do to focus on the isolated parts of the elephant. Since the organism of knowledge is a complex unitary whole, one requires multiple different perspectives to understand it in totality ${ }^{31}$. Thus, the present article, following Sellars' lead, only attempts to show that Kant's system contains a blueprint for an emergentist construal of CS. Whether there is some role for functionalism at some part in the system is another matter ${ }^{32}$.

\section{REFERENCES}

Achim, S. (1992). Emergence-A systematic view on its historical facets. In A. B. Kim and J. H. Flores (Eds.), Emergence or Reduction? (pp. 25-48). Berlin: De Gruyter.

Adler, I., \& Adler, R. (1962). Thinking machines. New York: Signet.

Alexander, S. I. (1920). Space, time, and deity. London: Macmillan.

Allen, R. (1966). Greek philosophy: Thales to Aristotle. New York: The Free Press.

Allison, H. (2004). Kant's transcendental idealism: An interpretation and defense. New Haven: Yale University Press.

Aristotle (2001). Metaphysics, the basic works of Aristotle. New York: Modern Library.

Bergson, H. (1944). Creative evolution. New York: Random House.

Bogen, J., \& Woodward, J. (1988). Saving the phenomena. Philosophical Review, 97, 303-352. http://dx.doi.org/10.2307/2185445

Breitenbach, A. (2011). Kant on causal knowledge: Causality, mechanism and reflective judgment. In K. Allen, \& T. Stoneham (Eds.), Causation and Modern Philosophy (pp. 201-219). London: Routledge.

Brighton, H. (2008). Introducing artificial intelligence. Portland, ME: Totem Books.

Brook, A. (1994). Kant and the mind. Cambridge and New York: Cambridge University Press. http://dx.doi.org/10.1017/CBO9780511624629

Brook, A. (2008). Kant's view of the mind and consciousness of the self. Stanford encyclopedia of philosophy.

http://plato.stanford.edu/entries/kant-mind/

Buchdahl, G. (1992). Kant and the dynamics of reason. Oxford: Blackwell.

Bunge, M. (1977). Emergence and the mind. Neuroscience, 2, 501-509.

Chrucky, A. (2008). An interview with David Armstrong about W. Sellars. Mikolka-Inquiries.

http://mikolka-inquiries.blogspot.mx/2008/11/interview-with-david-a rmstrong-about-w.html

Churchland, P. S. (1986). Neurophilosophy. Cambridge: MIT Press.

Clayton, P. (2008). Conceptual foundations of emergence theory. In Paul, D., \& Philip, C. (Eds.), The re-emergence of emergence: The emergentist hypothesis from science and religion (pp. 1-31). Oxford: Oxford University Press.

http://dx.doi.org/10.1093/acprof:oso/9780199544318.003.0001

Corradini, A., \& O’Connor (2010). Timothy, emergence in science and philosophy. New York: Routledge.

D’Abro, A. (1939). The decline of mechanism in modern physics. D. Van Nostrand Company, Inc.

Dartnall, T. (1996). Cognitive science and the crisis it is facing. Metascience, 5, 95-105. http://dx.doi.org/10.1007/BF02988881

Davidson, D. (1999). The emergence of thought. Erkentnis, 51, 511521. http://dx.doi.org/10.1023/A:1005564223855

Davies, P. (2008). Preface to the re-emergence of emergence: The emergentist hypothesis from science and religion, Paul Davies and Philip Clayton (Eds.), (pp. xi-xiv). Oxford: Oxford University Press. Dennett, D. (1981). Brainstorms. Cambridge: MIT.

\footnotetext{
${ }^{31}$ As the present author understands this point, the need for a multi-faceted perspectivist account derives from the unique nature of a living organism.

${ }^{32}$ It would not be possible to dedicate this paper to anyone other than the one and only Wilfrid Sellars.
} 


\section{R. MCDONOUGH}

Dreyfus, H. (1993). What computers still can't do. Cambridge: MIT. Eiser, J. R. (1991). Attitudes, chaos, and the connectionist mind. Oxford: Wiley-Blackwell.

Engels, F. (1994). Ludwig feuerbach and the end of classical german philosophy. Marx-Engels Internet Archive.

http://marxists.org/archive/marx/works/1886/ludwig-feuerbach/index h.htm

Fancher, R. (1990). Pioneers of psychology. New York: Norton.

Fodor, J. (1979). The language of thought. Cambridge, MA: Harvard University Press.

Fodor, J. (1987). Psychosemantics: The problem of meaning in the philosophy of mind. Cambridge, MA: MIT Press.

Fodor, J. (1998). Concepts: Where cognitive science went wrong. Oxford: Oxford University Press.

http://dx.doi.org/10.1093/0198236360.001.0001

Fodor, J. (2001). The mind doesn't work that way. Cambridge, MA: MIT Press.

Ginsborg, H. (2013). Kant's aesthetics and teleology. Stanford Encyclopedia of Philosophy. http://plato.stanford.edu/entries/kant-aesthetics/

Goldberg, B. (1983). Mechanism and meaning. In C. Ginet, \& S. Shoemaker (Eds.), Knowledge and Mind (pp. 191-210). Oxford: Oxford University Press.

Goudge, T. A. (1967). Emergent-evolutionism. In The encyclopedia of philosophy, vol. 2 (pp. 474-477). New York: Collier-Macmillan.

van Guick, R. (1992). Non-reductive physicalism and the nature of theoretic constraint. In J. Kim, A. Beckermann, \& H. Flores (Eds.), Emergence or reduction (pp. 157-179). Berlin: Walter De Gruyter.

Hansson, S. (2008). Science and pseudo science. Stanford Encyclopedia of Philosophy. http://plato.stanford.edu/entries/pseudo-science/

Hasker, W. (1999). The emergent self. Ithaca, NY: Cornell University Press.

Hegel, G. F. W. (1979). Phenomenology of spirit. Oxford: Oxford University Press.

Heidegger, M. (1962). Kant and the problem of metaphysics. Bloomington, IN: Indiana University Press.

Hempel, C. (1965). Aspects of scientific explanation. New York: Free Press.

Hodges, A. (2013). Alan Turing. Stanford Encyclopedia of Philosophy. http://plato.stanford.edu/entries/turing/\#MacInt

Kant, I. (1950). Prolegomena to any future metaphysics. New York: Bobbs-Merrill.

Kant, I. (1968). Critique is the critique of judgement. New York: Harper.

Kant, I. (1969). Critique of pure reason. New York: St Martin's Press.

Kant, I. (1970). Metaphysical foundations of natural science. Indianapolis, IN: Bobbs-Merrill.

Kant, I. (1983). What is Enlightenment? In Perpetual peace and other essays (pp. 41-48). Indianapolis, IN: Hackett.

Kant, I. (1996). Anthropology from a practical point of view. In V. Dowdell (Ed.), Carbondale, IL: Southern Illinois University Press.

Kant, I. (1998). Opus postumum. Cambridge: Cambridge University Press.

Kant, I. (2004). Critique of practical reason. New York: Dover.

Kim, J. Downward causation. In J. Kim, A. Beckermann, \& H. Flores (Eds.), Emergence or reduction (pp. 119-138). Berlin: De Gruyter.

Kim, J. (1993). Supervenience and mind. Cambridge: Cambridge University Press. http://dx.doi.org/10.1017/CBO9780511625220

Kitcher, Patricia (1984). Discovering the forms of intuition. The Philosophical Review, XCVI, 205-248.

Kitcher, Patricia (1990a). Kant's dedicated cognitive system. In J. C. Smith (Ed.), Historical Foundations of Cognitive Science (pp. 189209). New York: Springer.

Kitcher, Patricia (1990b). Kant's transcendental psychology. New York: Oxford University Press.

Kitcher, Philip (1982). How Kant almost wrote "Two Dogmas of Empiricism”. In J. N. Mohanty, \& R. Shahane (Eds.), Essays on Kant's critique of pure reason (pp. 217-250). Norman: University of Oklahoma Press.

Levin, J. (2013). Functionalism. Stanford Encyclopedia of Philosophy. http://plato.stanford.edu/entries/functionalism/

Lowe, E. J. (2000). Causal closure principles and emergentism. Philo- sophy, 75, 571-585.

http://dx.doi.org/10.1017/S003181910000067X

Margolis, J. (1986). Emergence. The Philosophical Forum, XVII, 271295.

Margolis, J. (1987). Science without unity. Oxford: Basil Blackwell.

McDonough, R. (1995). Kant's historicist alternative to cognitive science. The Southern Journal of Philosophy, 33, 203-219. http://dx.doi.org/10.1111/j.2041-6962.1995.tb00740.x

McDonough, R. (1997). Heidegger on Kant on the alternative to the scientism of the Enlightenment. The Journal for the British Society of Phenomenology, 28, 236-254.

McDonough, R. (1998). Kant's anti-scientism and the origins of phenomenology. The Journal for the British Society of Phenomenology, 29, 236-254.

McDonough, R. (1999a). Introduction to Wittgenstein and cognitive science. In R. McDonough (Ed.), Idealistic Studies, 29, 125-138.

McDonough, R. (1999b). Bringing cognitive science back to life. Idealistic Studies, 29, 173-213.

McDonough, R. (2002). Emergence and creativity: Five degrees of freedom. In T. Dartnall (Ed.), Creativity, cognition, and knowledge (pp. 283-320). Westport, CT: Praeger.

McDonough, R. (2006). Martin Heidegger's being and time. New York: Peter Lang.

McDonough, R. (2011). A synoptic view of Kant’s emergentism. Iyyun, $60,245-274$.

McGinn, C. (1989). Can we solve the mind-body problem? Mind, 98, 349-366.

http://art-mind.org/review/IMG/pdf/McGinn_1989_Mind-body-probl em_M.pdf

McGinn, C. (2004). Consciousness, atomism, and the ancient Greeks. In Consciousness and its objects (pp. 115-135). Oxford: Oxford University Press. http://consc.net/neh/papers/mcginn1.doc

McLaughlin, B. (1992). The rise and fall of British emergentism. In J. Kim, A. Beckermann, \& H. Flores (Eds.), Emergence or reduction (pp. 49-93). Berlin: De Gruyter.

Meerbote, R. (1990). Kant's functionalism. In J. C. Smith (Ed.), Historical foundations of cognitive science (pp. 161-188). New York: Springer.

Mill, J. S. (1999). Logic of the moral sciences. Indianapolis: Open Court.

Moore, G. E. (1994). Principia ethica. Cambridge: Cambridge University Press.

Morgan, L. (1923). Emergent evolution. London: Williams and Norgate.

Mourelatos, A. (1986). Quality, structure, and emergence in later presocratic philosophy. Proceedings in Boston Colloquium in Ancient Philosophy, 2, 127-194.

http://dx.doi.org/10.1163/2213441786X00129

Nagel, E. (1979). The structure of science. Indianapolis, IN: Hackett.

O'Connor, T. (2012). Emergent properties. Stanford Encyclopedia of Philosophy. http://plato.stanford.edu/entries/properties-emergent/

Palmquist, S. (1993). Kant's system of perspectives. Lanham, MD: University Press of America.

Palmquist, S. (2007). Emergence, evolution, and the geometry of logic: The myth of historical development. Foundations of Science, 12, 937. http://dx.doi.org/10.1007/s10699-006-0004-1

Pears, D. (1987). The false prison. Vol. I, Oxford: Oxford University Press. http://dx.doi.org/10.1093/0198247702.001.0001

Pepper, S. (1926). Emergence. Journal of Philosophy, 23, 241-245. http://www.ditext.com/pepper/emerge.html http://dx.doi.org/10.2307/2014779

Pinker, S. (2013). Language, cognition, and human nature: Selected articles. New York: Oxford University Press.

Pluher, W. (1987). Introduction and notes to Kant, Immanuel. Critique of judgment. Indianapolis, IN: Hackett.

Popper, K. (1950). The open society and its enemies. Princeton, NJ: Princeton University Press.

Popper, K. (1961). The poverty of historicism. New York: Harper.

Popper, K. (1972). Objective knowledge. Oxford: Oxford University Press.

Popper, K. (2002). Unended quest. New York: Routledge.

Putnam, H. (1964). Minds and machines. In A. R. Anderson (Ed.), 


\section{R. MCDONOUGH}

Minds and machines (pp. 72-97). Engelwood Cliffs, NJ: PrenticeHall.

Quine, W. V. (1951). Two dogmas of empiricism. Philosophical Review, 60, 20-43. http://dx.doi.org/10.2307/2181906

Reid, R. (2007). Biological emergences: Evolution by natural experiment. Cambridge, MA: MIT Press.

Rockwell, W. T. (2007). Neither brain nor ghost. Cambridge: Cambridge University Press.

Rosenberg, J. (2009). Wilfrid Sellars. Stanford Encyclopedia of Philosophy. http://plato.stanford.edu/entries/sellars/

Rueger, A. (2000). Physical emergence: Synchronic and diachronic. Synthese, 124, 297-322. http://dx.doi.org/10.1023/A:1005249907425

Russell, B. (1992). The analysis of matter. Cornwall: Routledge \& Kegan Paul.

Savin, H. B. (1973). A review of Katz's semantic analysis. Cognition, 2, 212-238. http://dx.doi.org/10.1016/0010-0277(72).90012-1

Schrader, G. (1967a). Kant's theory of concepts. In R. P. Wolff (Ed.), Kant: A collection of critical essays (pp. 134-155). New York: Doubleday.

Schrader, G. (1967b). The Thing-in-itself in Kantian philosophy. In R. P. Wolff (Ed.), Kant: A collection of critical essays (172-188). New York: Doubleday-Anchor.

Searle, J. (1983). Intentionality. Cambridge: Cambridge University Press. http://dx.doi.org/10.1017/CBO9781139173452

Searle, J. (1980). Minds, brains, and programs. Behavioral and Brain Sciences, 3, 417-457.

http://dx.doi.org/10.1017/S0140525X00005756

Sedgwick, S. (2012). Hegel's critique of Kant: From dichotomy to identity. Oxford: Oxford University Press. http://dx.doi.org/10.1093/acprof:oso/9780199698363.001.0001

Seibt, J. (1990). Properties as processes. Atascadero, CA: Ridgeview.

Sellars, R. W. (1970). Principles of emergent realism. St. Louis, MO:

Warren H. Green.

Sellars, W. (1949). Aristotelian philosophies of mind. Philosophy for the future: Quest for modern materialism (pp. 544-570). New York: Macmillan. http://www.ditext.com/sellars/apm.html

Sellars, W. (1991a). Philosophy and the scientific image of man. Science, perception, and reality (pp. 1-40). Atascadero, CA: Ridgeview.

Sellars, W. (1991). "Phenomenalism”. In Science, perception and reality (pp. 60-105). Atascadero, CA: Ridgeview.

Sellars, W. (1968). Science and metaphysics. New York: Routledge and Kegan Paul.

Sellars, W., \& Meehl, P. E. (1956). The concept of emergence. Vol. l. In H. Feigl, \& M. Scriven (Eds.), Minnesota studies in the philosophy of science (pp. 239-252). Minneapolis, MN: University of Minnesota Press.

Shoemaker, S. (2002). Kim on Emergence. Philosophical Studies, 58, 53-63. http://philpapers.org/s/sydney\%20shoemaker

Strawson, P. (1963). Individuals. New York: Doubleday and Co.

Strawson, P. (1968). The bounds of sense. London: Metheun.

Wallace, W. (1894). Prolegomena to the study of Hegel's philosophy. Oxford: Clarendon Press.

Watson, J. (1892). Schelling's transcendental idealism. Chicago, IL: S. C. Griggs \& Company.

Weiskopf, D. (2011). Models and mechanisms in psychological explanation. Synthese, 183, 313-338.

http://dx.doi.org/10.1007/s11229-011-9958-9

Whitehead, A. N. (1967). Science and the modern world. New York: The Free Press.

Whitehead, A. N. (1978). Process and reality. In D. Griffin, \& D. Sherburne (Eds.), New York: Free Press.

Wittgenstein, L. (1980). Culture and value. Chicago, IL: University of Chicago Press.

Zumbach, C. (1984). The transcendent science: Kant's conception of biological methodology. The Hague, Boston, Lancaster: MartinusNijhoff. http://dx.doi.org/10.1007/978-94-009-6104-3 